\title{
PENGARUH PEMBELAJARAN PERMAINAN BOLA KECIL TERHADAP NILAI DISIPLIN SISWA PADA MATA PELAJARAN PASCA PENDIDIKAN JASMANI
}

\author{
Ummahatul Illiyyin Al Fath Ermadinoto $^{1)}$, Mudjihartono ${ }^{2)}$, Arif Wahyudi ${ }^{3)}$ \\ Universitas Pendidikan Indonesia \\ email: mudji@upi.edu
}

\begin{abstract}
Abstrak
Penelitian ini bertujuan untuk mengetahui bagaimana pengaruh pembelajaran permainan bola bakar terhadap nilai disiplin siswa pada mata pelajaran pasca pendidikan jasmani kelas VIII di SMP Negeri 2 Subang. Metode penelitian yang digunakan adalah eksperimen. Perlakuan diberikan sebanyak 12 kali pertemuan. Teknik pengambilan sampel yang digunakan adalah purposive sampling. Populasi dalam penelitian ini adalah siswa kelas VIII SMP Negeri 2 Subang. Sedangkan sampel penelitian ini adalah 44 siswa kelas VIII B. Instrumen yang digunakan adalah angket dan observasi. Angket yang valid sebanyak 39 butir soal dari 50 butir soal. Untuk uji reliabilitas diperoleh $t_{\text {hitung }}(20,095) \geq t_{\text {tabel }}(2,040)$, yang berarti bahwa angket dinyatakan reliabel. Dari hasil pengolahan data diperoleh $t_{\text {hitung }}$ $(2,1350)>t_{\text {tabel }}(1,68)$, dengan demikian hipotesis nol $\left(\mathrm{H}_{0}\right)$ ditolak. Maka, dapat disimpulkan bahwa terdapat pengaruh yang signifikan terhadap nilai disiplin siswa pada mata pelajaran pasca pendidikan jasmani melalui pembelajaran permainan bola kecil (permainan bola bakar) di SMP Negeri 2 Subang.
\end{abstract}

Kata kunci : Pembelajaran Permainan Bola Kecil, Permainan Bola Bakar, Nilai Disiplin Siswa

\section{PENDAHULUAN}

Manusia dalam melaksanakan kehidupannya tidak akan lepas dari pendidikan, karena pendidikan berfungsi untuk meningkatkan kualitas manusia itu sendiri baik individu maupun kelompok, jasmani, rohani, materi dan kemampuan berfikirnya. Dengan kata lain pendidikan bertujuan untuk meningkatkan sumber daya manusia.

Untuk memaksimalkan proses pendidikan yang lebih baik pendidikan jasmani merupakan wadah untuk mengembangkan nilai-nilai kognitif, afektif, dan psikomotor anak melalui proses pembelajaran. Karena tidaklah cukup suatu rangkaian kurikulum di sekolah tanpa adanya mata pelajaran pendidikan jasmani. Pendidikan jasmani merupakan mata pelajaran yang unik, karena pendidikan jasmani dapat mengembangkan nilai-nilai kognitif, afektif, dan psikomotor anak melalui proses pembelajaran.

Dalam Standar Kompetensi Kompetensi Dasar (SKKD) pendidikan jasmani baik itu di Sekolah Dasar (SD), Sekolah Menengah Pertama (SMP), sampai Sekolah Menengah Atas (SMA) banyak menggunakan permainan dalam pembelajaran. Di dalam Standar Kompetensi Kompetensi Dasar (SKKD) juga selalu disebut kata-kata sportivitas, kejujuran, 
kerjasama, toleransi, disiplin, dan percaya diri. Ini merupakan aspek afektif anak yang di dalamnya ada nilai-nilai sosial yang dapat dikembangkan dan ditingkatkan oleh anak melalui proses pembelajaran yang dibimbing oleh guru.

Permainan bola bakar merupakan salah satu permainan bola kecil yang pada saat ini sudah jarang sekali dimainkan oleh anak usia Sekolah Menengah Pertama (SMP), padahal dalam permainan tersebut mengandung banyak nilai-nilai yang dapat diambil sebagai pendidikan. Dalam permainan ini anak dituntut memiliki nilai kerjasama yang baik dengan teman kelompoknya karena keberhasilan kelompoknya tergantung pada kebersamaan kelompok dan dapat memenangkan permainan.

Agar terbentuknya kebersamaan yang kuat maka masing-masing individu harus memiliki nilai disiplin yang baik. Nilai disiplin dipupuk saat latihan berlangsung atau dalam proses pembelajaran berlangsung. Karena bila nilai disiplin sudah ditanam sejak dini maka anak akan terbiasa disiplin dan bertanggungjawab pada setiap kegiatannya.

Prijodarminto (1994) dalam Tu'u (2004:31) (Nurdinkhan, 2012 : http://nurdinkhan.wordpress.com/2012/05/30/angket-kedisiplinan-siswa/) juga memaparkan bahwa 'disiplin adalah suatu kondisi yang tercipta dan berbentuk melalui proses dari serangkaian perilaku yang menunjukan nilai-nilai ketaatan, kepatuhan, kesetiaan, keteraturan dan keterikatan'. Dapat disimpulkan bahwa disiplin merupakan suatu kondisi dimana seseorang berlaku mematuhi tata tertib dan peraturan yang sudah ditetapkan sebelumnya dengan kesadaran dari dalam diri maupun karena mendapatkan hukuman (punishment). Dengan adanya disiplin dalam diri seseorang maka akan tercipta suatu keteraturan di dalam kelompok.

Tanpa adanya sikap disiplin dari setiap individu dalam sebuah kelompok maka tidak akan terlihat atau tercipta suatu keteraturan. Keteraturan ini penting guna menciptakan keadaan yang rapi, tertib, dan terkendali.

Sekolah merupakan tempat untuk melatih sikap disiplinnya, karena sekolah merupakan ajang anak untuk bersosialisasi sambil menerapkan sikap disiplinnya, dimana sekolah memiliki peraturan secara tertulis yang sudah ditetapkan dan siswa tidak boleh melanggarnya. Siswa yang memiliki nilai disiplin pasti akan bertanggungjawab dengan apa yang dilakukannya. Hal ini dapat berpengaruh terhadap keberhasilan kegiatan belajar siswa. Bagi siswa yang memiliki nilai disiplin dan tanggungjawab yang baik pada umumnya mereka akan berusaha sebaik mungkin dalam proses pembelajaran karena mereka sadar bahwa sebuah tujuan pembelajaran tidak akan tercapai bila tidak ada usaha yang cukup dari diri mereka sendiri.

Pada mata pelajaran pendidikan jasmani di sekolah siswa pasti diajarkan sikap disiplin sebagai salah satu nilai afektif yang ada pada pendidikan jasmani. Sikap ini sengaja diajarkan agar tertanam dalam diri siswa dan siswa dapat mempraktikkannya dalam kegiatan di sekolah atau kehidupan sehari-hari di masyarakat. Melalui permainan bola bakar, tanpa disadari anak terlibat dalam proses pendidikan yang akan bermanfaat bagi nilai kognitif, afektif, dan psikomotornya. Selain itu nilai disiplin yang ada pada permainan bola bakar dapat diterapkan pada berbagai kegiatan, baik itu kegiatan di sekolah maupun kegiatan sehari-hari.

Melalui pembelajaran permainan bola kecil (permainan bola bakar) yang dilaksanakan pada kelas VIII di SMP Negeri 2 Subang, diharapkan siswa dapat menerapkan nilai disiplin yang dibentuk pada saat pembelajaran berlangsung, minimal pada mata pelajaran pasca pendidikan jasmani yaitu mata pelajaran Teknologi Informatika dan Komunikasi (TIK). Penulis mengambil mata pelajaran ini karena dibandingkan dengan mata pelajaran lain yang orientasinya di dalam kelas, TIK merupakan mata pelajaran yang memberikan lebih banyak kesempatan kepada anak untuk menerapkan nilai disiplin yang sesuai dengan ketentuan 
laboratorium komputer dan sekolah sambil bisa bersosialisasi dan bekerjasama dengan teman dalam mengerjakan tugas yang diberikan oleh guru di dalam kelas.

\section{METODE PENELITIAN}

Metode penelitian yang akan dipergunakan dalam penelitian ini adalah metode eskprimen dengan desain penelitian yaitu one-group pretest-posttest design yang terdapat di dalam pre-eksperimental design (nondesign). Dalam hal ini Riduwan (2011:50) mejelaskan bahwa "Penelitian dengan pendekatan eksperimen adalah suatu penelitian yang berusaha mencari pengaruh variabel tertentu terhadap variabel yang lain dalam kondisi yang terkontrol secara ketat."

\subsection{Populasi dan Sampel}

Populasi dalam penelitian ini adalah siswa kelas VIII SMP Negeri 2 Subang. Sedangkan sampel penelitian ini adalah 44 siswa kelas VIII B dengan teknik pengambilan sampel menggunakan purposive sampling yaitu pengambilan sampel yang bertujuan. Jadi pengambilan subjek bukan didasarkan atas strata, random atau daerah tetapi berdasarkan adanya tujuan tertentu, yaitu kelas yang memiliki jadwal mata pelajaran TIK setelah mata pelajaran pendidikan jasmani.

\subsection{Instrumen}

Untuk instrumen penelitian ini penulis menggunakan observasi dan angket sebagai alat pengumpul datanya.

Angket disebarkan kepada siswa yang telah ditentukan sebagai sampel (responden) berisi pernyataan-pernyataan mengenai sikap disiplin siswa pada mata pelajaran pasca pendidikan jasmani. Siswa hanya diminta untuk memberikan tanda checklist $(\sqrt{ })$ pada kolom yang telah tersedia yaitu kolom Sangat Setuju (SS), Setuju (S), Ragu-ragu (R), Tidak Setuju (TS), atau Sangat Tidak Setuju (STS). Terdapat skor di masing-masing alternatif jawaban pada angket, yaitu dari skor lima sampai dengan satu. Angka lima menunjukan bahwa pernyataan yang ada pada angket melekat dalam diri responden, semakin rendah skor yang dipilih oleh responden maka semakin jauh dari diri responden. Terdapat pernyataan positif dan negatif dalam angket tersebut.

Untuk lembar observasi dipegang oleh peneliti untuk melihat perkembangan nilai disiplin siswa pada saat mata pelajaran pasca pembelajaran pendidikan jasmani.

\section{Pengolahan dan Analisis Data}

Data yang diperoleh peneliti dari penyebaran angket nilai disiplin siswa pada mata pelajaran pasca pendidikan jasmani selanjutnya dilakukan pengolahan data menggunakan metode statistika. Teknik pengolahan data dalam penelitian ini dilakukan secara manual dan menggunakan Microsoft Office Exel 2007. Langkah-langkah yang penulis gunakan untuk mengolah data tersebut adalah sebagai berikut:

1. Menghitung skor rata-rata angket pretest dan posttest.

2. Menghitung simpangan baku angket pretest dan posttest.

3. Menguji Normalitas data menggunakan uji kenormalan Lilliefors.

4. Menguji homogenitas menggunakan uji kesamaan dua variansi.

5. Menguji hipotesis menggunakan uji satu pihak. 


\section{HASIL DAN PEMBAHASAN}

\subsection{Hasil}

1. Menghitung skor rata-rata dan simpangan baku dari data angket pretest dan posttest

Dibawah ini merupakan tabel hasil perhitungan nilai rata-rata $(\bar{X})$ dan simpangan baku (s) dari data angket pretest dan posttest:

\section{Tabel 1. Hasil Perhitungan Nilai Rata-Rata $(\bar{X})$ Dan Simpangan Baku (s) Dari Data Angket Pretest Dan Posttest}

\begin{tabular}{|c|c|c|}
\hline $\begin{array}{c}\text { Hasil } \\
\text { Perhitungan }\end{array}$ & Pretest & Posttest \\
\hline $\begin{array}{c}\text { Nilai Rata- } \\
\text { rata }(\bar{X})\end{array}$ & 173.8409 & 183.2955 \\
\hline $\begin{array}{c}\text { Simpangan } \\
\text { Baku (s) }\end{array}$ & 9.7812 & 6.1553 \\
\hline
\end{tabular}

Dari tabel di atas dengan jumlah sampel sebanyak 44 orang, diperoleh nilai rata-rata untuk pretest yaitu 173,8409 dengan simpangan baku 9,7812 dan posttest 183,2955 dengan simpangan baku 6,1553 .

\section{Pengujian Persyaratan Analisis}

Uji normalitas dilakukan dengan tujuan untuk menguji apakah data dari hasil penelitian yang telah dilaksanakan berdistribusi normal atau tidak. Uji normalitas ini menggunakan uji normalitas dari Liliefors yang dianggap lebih mudah dan praktis.

Tabel 2. Hasil Perhitungan Uji Normalitas Data Pretest Dan Posttest Dengan Pendekatan Uji Liliefors

\begin{tabular}{|c|c|c|c|c|}
\hline $\begin{array}{c}\text { Jenis } \\
\text { Test }\end{array}$ & $\mathbf{n}$ & $\mathbf{L}_{\mathbf{0}}$ & $\mathbf{L}_{\mathbf{t}}$ & Kesimpulan \\
\hline Pretest & 44 & 0.0686 & 0.1336 & Normal \\
\hline Posttest & 44 & 0.0989 & 0.1336 & Normal \\
\hline
\end{tabular}

Dari tabel di atas dengan taraf nyata $\alpha=0,05$ dan jumlah sampelnya adalah 44 orang, dapat diketahui bahwa hasil pretest dan posttest nilai disiplin siswa pada mata pelajaran pasca pendidikan jasmani di SMP Negeri 2 Subang masing-masing mempunyai nilai $\mathrm{L}_{0}=$ 0,0686 dan 0,0989 dengan $\mathrm{L}_{\mathrm{t}}=0,1336$, maka untuk data pretest nilai $\mathrm{L}_{0}(0,0686)<\mathrm{L}_{\mathrm{t}}$ $(0,1336)$ sehingga hipotesis diterima yang artinya data pretest tersebut berdistribusi normal. Dan untuk data posttest nilai $\mathrm{L}_{0}(0,0989)<\mathrm{L}_{\mathrm{t}}(0,1336)$ sehingga hipotesis diterima yang artinya data posttest tersebut berdistribusi normal.

Setelah uji normalitas dan data yang didapat berdistribusi normal, langkah selanjutnya yaitu peneliti melakukan uji homogenitas dengan uji kesamaan dua variansi yang tujuannya 
yaitu untuk mengetahui homogen tidaknya data dari kelompok sampel dalam suatu penelitian. Hasil pengujian homogenitas dapat dilihat pada tabel 3.

Tabel 3. Hasil Perhitungan Uji Homogenitas

\begin{tabular}{|c|c|c|c|c|}
\hline $\begin{array}{c}\text { Jenis } \\
\text { Tes }\end{array}$ & $\mathbf{n}$ & $\boldsymbol{F}_{\text {hitung }}$ & $\boldsymbol{F}_{\text {tabel }}$ & Kesimpulan \\
\hline $\begin{array}{c}\text { Pretest } \\
\text { Dan } \\
\text { Posttest }\end{array}$ & 44 & 2,5252 & 1.66 & Homogen \\
\hline
\end{tabular}

Dari tabel 4.3 di atas taraf nyata $\alpha=0.05$ dan $\mathrm{dk}\left(\mathrm{n}_{1}-1 ; \mathrm{n}_{2}-1\right)$ dapat diketahui bahwa data hasil pretest dan posttest nilai disiplin siswa pada mata pelajaran pasca pendidikan jasmani di SMP Negeri 2 Subang mempunyai $F_{\text {hitung }}=2,5252$ dan $F_{\text {tabel }}=1,66$ oleh karena $F_{\text {hitung }}(2,5252)<F_{\text {tabel }}(1,66)$ maka hipotesisnya diterima bahwa tidak terdapat perbedaan variansi yang signifikan atau data tersebut dinyatakan homogen.

\section{Pengujian Hipotesis}

Untuk menguji hipotesis menggunakan uji satu pihak. Dengan menggunakan uji kesamaan dua rata-rata (satu pihak) dapat menggambarkan bahwa terdapat pengaruh yang signifikan atau tidak mengenai pembelajaran permainan bola kecil (permainan bola bakar) terhadap nilai disiplin siswa pada mata pelajaran pasca pendidikan jasmani di SMP Negeri 2 Subang. Berikut ini tabel ringkasan hasil uji kesamaan dua rata-rata (satu pihak).

\section{Tabel 4. Uji Kesamaan Dua Rata-Rata Nilai Disiplin Siswa Pada Mata Pelajaran Pasca Pendidikan Jasmani}

\begin{tabular}{|c|c|c|c|}
\hline $\begin{array}{c}\text { Jenis } \\
\text { Tes }\end{array}$ & $\mathbf{t}_{\text {hitung }}$ & $\mathbf{t}_{\text {tabel }}$ & Kesimpulan \\
\hline $\begin{array}{c}\text { Pretest } \\
\text { Dan } \\
\text { Posttest }\end{array}$ & 5,4266 & 1,663 & Signifikan \\
\hline
\end{tabular}

Untuk kriteria pengujian kesamaan dua rata-rata (satu pihak) ialah, terima $\mathrm{H}_{0}$ jika: $\mathrm{t}_{\text {hitung }}<\mathrm{t}_{\text {tabel }(1-\alpha)}$ dalam hal lain $\mathrm{H}_{0}$ ditolak. dk untuk daftar distribusi $\mathrm{t}$ adalah $\mathrm{n}_{1}+\mathrm{n}_{2}-2$, dengan peluang $(1-\alpha)$, dengan $\alpha=0,05$, maka diperoleh $(0,95: 86)$, dan $t_{\text {tabel }}=1,663$.

Ternyata $t_{\text {hitung }}(5,4266)>\mathrm{t}_{\text {tabel }}(1,663)$, maka $\mathrm{H}_{0}$ ditolak. Maka dapat disimpulkan bahwa terdapat pengaruh yang signifikan terhadap nilai disiplin siswa pada mata pelajaran pasca pendidikan jasmani melalui pembelajaran permainan bola kecil (permainan bola bakar) di SMP Negeri 2 Subang.

\subsection{Pembahasan}

Berdasarkan dari semua penjelasan serta teori yang digunakan mengenai pengaruh pembelajaran permainan bola kecil (permainan bola bakar) terhadap nilai disiplin siswa pada mata pelajaran pasca pendidikan jasmani di SMP Negeri 2 Subang dengan sampel penelitian kelas VIII B dan mata pelajaran pasca pendidikan jasmani yang digunakan yaitu Teknologi Informatika dan Komunikasi (TIK), penulis mendapatkan hasil dari pengolahan dan analisis data bahwa ternyata $t_{\text {hitung }}(5,4266)>t_{\text {tabel }}(1,663)$, yang artinya $\mathrm{H}_{0}$ ditolak dan 
$\mathrm{H}_{1}$ diterima yaitu terdapat pengaruh yang signifikan dari pembelajaran permainan bola bakar terhadap nilai disiplin siswa pada mata pelajaran pasca pendidikan jasmani di SMP Negeri 2 Subang. Jadi melalui pembelajaran permainan bola bakar dapat meningkatkan nilai disiplin siswa pada mata pelajaran Teknologi Informatika dan Komunikasi (TIK) yang dilaksanakan pasca pendidikan jasmani di SMP Negeri 2 Subang.

Hal ini sejalan dengan pernyataan dari Hartono (2009:204) dalam jurnalnya yang berjudul Memberdayakan Olahraga Nasional bahwa, Olahraga yang dilakukan dengan tepat dan benar akan menjadi faktor penting yang sangat mendukung untuk pengembangan potensi diri. Kesehatan, kebugaran jasmani dan sifat-sifat kepribadian yang unggul adalah faktor yang sangat menunjang untuk pengembangan potensi diri manusia, dan melalui pendidikan jasmani, rekreasi, dan olah raga yang tepat faktor-faktor tersebut dapat diperoleh. Melalui pembinaan olahraga yang sistematis, kualitas SDM dapat diarahkan pada peningkatan pengendalian diri, tanggung jawab, disiplin, sportivitas yang tinggi yang mengandung nilai transfer bagi bidang lainnya.

Dengan terlihatnya hasil yang nyata bahwa nilai disiplin siswa pada mata pelajaran pasca pendidikan jasmani dapat dipengaruhi oleh pembelajaran permainan bola kecil (permainan bola bakar), maka akan membuat suasana kelas yang lebih nyaman dan tertib. Selain itu juga nilai disiplin siswa di luar kelas dapat tercipta lebih baik lagi. Ini merupakan nilai tambahan sikap bagi siswa yang akan diberikan oleh guru yang bersangkutan.

Nilai disiplin sangatlah penting dimiliki siswa atau semua umat manusia guna menciptakan suasana lebih nyaman dan tertib. Seseorang yang memiliki nilai disiplin yang cukup baik maka akan memiliki tanggung jawab terhadap dirinya sendiri dan juga dapat diandalkan oleh orang-orang sekitarnya. Hal ini sangat bermanfaat bagi kehidupan sosial di masyarakat.

Jadi peningkatan nilai disiplin seseorang dapat dipengaruhi oleh faktor internal atau dalam diri yang berdasarkan kesadaran diri dan faktor eksternal yang didapat dari pengaruh lingkungan, serta dapat dipengaruhi oleh pelaksanaan olahraga yang dilakukan dengan tepat, benar, dan secara sistematis. Karena untuk mencapai keberhasilan dan kesuksesan suatu hal dimulai dari mendisiplinkan diri sendiri dan bertanggung jawab terhadapnya.

\section{KESIMPULAN}

Berdasarkan hasil pengolahan dan analisis data dari pretest dan posttest angket nilai disiplin siswa pada mata pelajaran pasca pendidikan jasmani, maka kesimpulan dari hasil penelitian ini adalah terdapat pengaruh yang signifikan terhadap nilai disiplin siswa pada mata pelajaran pasca pendidikan jasmani melalui pembelajaran permainan bola kecil (permainan bola bakar) di SMP Negeri 2 Subang.

Hal ini juga dapat disimpulkan bahwa semakin baik nilai disiplin siswa maka akan tercipta lingkungan kelas yang semakin nyaman dan tertib pula.

Dari paparan di atas, hal ini menunjukkan bahwa melalui pembelajaran permainan bola kecil (permainan bola bakar) memberikan dampak positif terhadap nilai disiplin siswa pada mata pelajaran pasca pendidikan jasmani di SMP Negeri 2 Subang. 


\section{REFERENSI}

Abduljabar, B. (2010). Landasan Ilmiah Pendidikan Intelektual Dalam Pendidikan Jasmani. Bandung : Rizqi Press.

Abduljabar, B. dan Darajat, Djajat, K.N. (2010). Modul Aplikasi Statistika Dalam Penjas. Bandung : Universitas Pendidikan Indonesia.

Agus, M. (2009). Asas dan Falsafah Pendidikan Jasmani. Bandung : Universitas Pendidikan Indonesia.

Ahmadi, Abu. dan Uhbiyanti, Nur. (2001). Ilmu Pendidikan. Jakarta: Rineka Cipta.

Arikunto, Suharsimi. (2010). Prosedur Penelitian Suatu Pendekatan Praktik Edisi Revisi 2010. Jakarta: Rineka Cipta.

Asmara, Andri Anggaria Arizona. (2013). Perbandingan Pendekatan Bermain dan Pendekatan Konvensional dalam Pembelajaran Pendidikan Jasmani Terhadap Minat Belajar Mata Pelajaran Pasca Pendidikan Jasmani. Skripsi PJKR FPOK UPI Bandung : Tidak Diterbitkan.

Dra. Tite Juliantine, M.Pd, Drs. Yunyun Yudiana, M.Pd, \& Drs. Herman Subarjah, M.Si. (2007). Teori Latihan. Bandung: Universitas Pendidikan Indonesia.

Hadjarati, Hartono, M.Pd. (Mei 2009). Memberdayakan Olah Raga Nasional. [PDF]. Jurnal Pelangi Ilmu Volume 2 NO. 5. Tersedia: ejurnal.ung.ac.id/index.php/JPI/article/ download/600/551. [26 Juni 2013]

Mardia Bin Smith. Pengaruh Layanan Konseling Kelompok Terhadap Disiplin Belajar Siswa Di Sma Negeri 1 Atinggola Kabupaten Gorontalo Utara. [PDF]. Tersedia: jurnal.djulas.com/jurnal/MARDIA\%20OK\%20pix.pdf. [3 April 2013]

Nurdinkhan. (30 Mei 2012). Angket kedisiplinan Siswa. [Online]. Tersedia: http://nurdinkhan.wordpress.com/2012/05/30/ angket-kedisiplinan-siswal. [5 April 2013]

Riduwan. (2011). Belajar Mudah Penelitian Untuk Guru-Karyawan dan Peneliti Muda. Bandung : Alfabeta.

Slameto. (2003). Belajar dan Faktor-Faktor yang Mempengaruhinya. Jakarta : PT. Rineka Cipta.

Subarjah, Herman. (2008). Bahan ajar permainan bola kecil. Bandung : Universitas Pendidikan Indonesia. 
Sudjana. (2005). Metoda Statistika Edisi 6. Bandung : PT. Tarsito Bandung.

Sugiyono. (2012). Metode Penelitian Pendidikan (Pendekatan Kuantitatif, Kualitatif, dan $R \& D)$. Bandung : Alfabeta.

Suharjana, F. (2007). Pembelajaran Permainan Bola Kecil, Senam Artistik, dan Aktivitas Pengembangan Dalam Pendidikan Jasmani di SD. [PDF]. Materi Pada Penataran Kegiatan Belajar Mandiri di PKB/PGB Pendidikan Jasmani SD, Yogyakarta. [9 Desember 2012]

Suparlan, Ajang., Mudjihartono. dan Darajat, Djajat, K.N. (2010). Modul Pembelajaran Permainan Bola Kecil. Bandung : Universitas Pendidikan Indonesia.

Suparman. (2007). Model Kurikulum Tingkat Satuan Pendidikan (KTSP) SMP dan MTs. [PDF]. Solo: PT Tiga Serangkai Pustaka Mandiri. [18 Maret 2012]

Zahrifah, Fitria Lailatus. dan Darminto, Eko. Penggunaan Strategi Pengelolaan Diri untuk Meningkatkan Disiplin Belajar Siswa. [PDF]. Tersedia: ppb.jurnal.unesa.ac.id/ bank/.../11._artikel_Fitria_dan_darminto.pdf. [5 April 2013]

. Definisi 'ajar'. [Online]. Tersedia: http://www.artikata.com/arti-4379-ajar.html. [9 Desember 2012]

Pengertian Pembelajaran Menurut Para Ahli| Definisi, Tujuan, Prinsip, Ciri. [Online]. Tersedia: http://www.sarjanaku.com/2012/11/pengertian-pembelajaranmenurut-para.html. [9 Desember 2012]

Undang-Undang Republik Indonesia Nomor 20 Tahun 2003 Tentang Sistem Pendidikan Nasional. [PDF]. Tersedia: www.hukumonline.com. [2 Januari 2013] 